\title{
THE ROLE OF THE PERIOPERATIVE NURSING CARE IN THE SATISFACTION OF PATIENTS AFTER LARGE JOINT REPLACEMENTS
}

D0l: 10.36740/WLek202009103

\author{
Iwona Morawik' ${ }^{1}$, Monika Gospodarek ${ }^{1}$, Karolina Turżańska ${ }^{2}$, Aneta Zarębska ${ }^{2}$, Anna Serefko ${ }^{3}$, Mirosław Jabłoński ${ }^{2}$ \\ 'DEPARTMENT OF ANAESTHESIOLOGICAL NURSING AND INTENSIVE MEDICAL CARE, MEDICAL UNIVERSITY OF LUBLIN, LUBLIN, POLAND \\ ${ }^{2}$ CHAIR AND DEPARTMENT OF REHABILITATION AND ORTHOPAEDICS, MEDICAL UNIVERSITY OF LUBLIN, LUBLIN, POLAND \\ ${ }^{3}$ DEPARTMENT OF APPLIED AND SOCIAL PHARMACY, LABORATORY OF PRECLINICAL TESTING, MEDICAL UNIVERSITY OF LUBLIN, LUBLIN, POLAND
}

\begin{abstract}
The medical services market is inevitably changing. Competition among health care institutions is growing, patients' health awareness and expectations regarding the quality of health services are increasing. This translates directly into, among others, to the patient's choice of medical facility. "Satisfaction" defined as "general satisfaction accompanying the consumption of products or services" is an important aspect affecting the position of a healthcare institution on the health services market. While in the hospital, the patient carefully observes and remembers many details of behaviors and reactions he encounters. Opinions of patients about a medical facility are usually subjective and relate mainly to satisfaction with the treatment process, therefore the lack of proper care in terms of patients' needs may result in the loss of the hospital's reputation. A very important aspect of the assessment of any medical service is the direct relationship between the patient and medical staff, mainly nurse. Among the factors affecting the level of patient satisfaction during a hospital stay are, inter alia, the availability of a doctor, nursing care, conditions in the ward, the possibility of patient participation in the treatment process, providing the patient with information in a clear and reliable manner, and improved health. Factors related to nursing care that have the greatest impact on the patient's level of satisfaction comprise the nurse's individual approach to the patient, time devoted to him, providing professional information, patient education and scrupulous nursing activities. The aim: The aim of the paper was to assess the role of perioperative nursing care in the satisfaction of patients after hip and knee joint replacements.
\end{abstract}

KEY WORDS: satisfaction, perioperative, joint replacements, nursing care

Wiad Lek. 2020;73(9 p. I):1824-1828

\section{INTRODUCTION}

The related bibliography presents numerous evidence that patient satisfaction with a medical procedure often has nothing to do with medical services in themselves. Factors include the patient's age, level of education, patient's race and sex, and race and sex of health care professionals he came into contact with, waiting time for an appointment, location of the center, mental state of the patient, as well as the time between providing medical services and conducting a survey [1 ]. The medical services market is inevitably changing. Competition among health care institutions is steadily growing, patients' health awareness and expectations regarding the quality of health services are increasing $[2,3]$. This translates directly into, among others patient's choice of a medical facility [4-7]. "Satisfaction" defined as "general satisfaction accompanying the consumption of products or services" is an important aspect affecting the position of a healthcare institution on the health services market [8]. The expectation to meet medical needs is a factor that significantly determines the choice of a medical facility by the patient. Meeting these expectations contributes to a better assessment of the facility and also increases the chances of constant interest of patients in a given health institution $[4-7,9]$. A number of studies analyzing patient satisfaction with medical services prove the existence of a relationship between patient satisfaction and their loyalty. Therefore, a satisfied patient identifies with the facility in which he received help and recommends it to others $[10,11]$.

\section{THE AIM}

The aim of the paper was to assess the role of perioperative nursing care in the satisfaction of patients after hip and knee joint replacements.

\section{REVIEW AND DISCUSSION}

\section{DEFINITION}

The term "satisfaction" (Latin satis - sufficiently, facere - to do) is most often defined as "general satisfaction accompanying the consumption of products or services" [8]. According to another definition, "the level of customer satisfaction is a reflection of the extent to which the total product offered by an organization satisfies the set of customer requirements" [12]. Satisfaction is a subjective feeling, largely depending on the character traits of the service / product buyer, his requirements and quality perception. R. B. Woodruff and S.F. Gardial says that satisfaction is a 
"positive or negative feeling of the customer in relation to the value he received as a result of using a specific product offer in a specific situation" [13]. Risser believes that the word "satisfaction" means a degree of agreement between expectations and what the client actually receives [15]. Czerw defines this term differently, claiming that it is "general satisfaction accompanying the consumption of products or services" [8]. According to the next definition, "the level of customer satisfaction is a reflection of the extent to which the total product offered by an organization satisfies the set of customer requirements" [12].

\section{MEDICAL SATISFACTION}

While in the hospital, the patient carefully observes and remembers many details of behaviors and reactions he encounters. Opinions of patients about a medical facility are usually subjective and relate mainly to contentment and satisfaction with the treatment process, therefore the lack of proper care in terms of patients' needs may result in the loss of the hospital's reputation [3]. In medical facilities, a high level of satisfaction is achieved due to factors such as understanding and meeting the patient's requirements [15]. A very important aspect of the assessment of any medical service is the relationship between the patient and medical staff. This interaction has a significant impact on the overall service process and patient satisfaction [16]. A patient who is satisfied with nursing care more closely follows and trusts the recommendations of medical staff [17]. Among factors affecting the level of patient satisfaction during a hospital stay are, among others, the availability of a doctor, nursing care, conditions in the ward, the possibility of patient participation in the treatment process, providing the patient with information in a clear and reliable manner $[3,7,11,18]$. According to most research, among the listed factors, nursing care provided continuously and reliably is one of the most important elements of a subjective, comprehensive assessment of hospitalization $[19,20]$.

\section{NURSING CARE AND PATIENT SATISFACTION}

Factors related to nursing care that have the greatest impact on the patient's level of satisfaction are as follows: the nurse's individual approach to the patient, time devoted to him, providing professional information, patient education and scrupulous nursing activities [3,21,22]. For patients, the attitude of a nurse and her appearance, neatness, care, kindness and understanding are of great importance [23, 24]. During hospitalization, patients are often accompanied by fear of their own life and health, and fear of family circumstances [25]. The nurse is usually the first person to contact with the patient after admission to the hospital ward, and therefore in her work the individual approach and recognition of the biopsycho-social needs of each patient is of great importance. Her attitude and empathy towards the sick are also very important. All these factors affect the patient's well-being and sense of security during hospitalization [26].

\section{CHARACTERISTICS OF NURSING CARE IN THE OPERATING THEATER}

A patient qualified for surgery is transported by two nurses from the ward or a nurse and a paramedic - always by two people, in accordance with safety standards developed in the hospital. In the mucus for patients, the patient is picked up by the staff of the operating side, most often by the anaesthesiological nurse and instrumentalist (operating nurse). At this stage, the patient's identity is confirmed, the completeness of the necessary medical documentation including current test results, blood group, consent to anesthesia and surgery and others is checked. The operating theater staff makes psychological contact with the patient to minimizes stress, makes sure that the patient maintains food and fluid withdrawal, asks if he has taken the necessary pharmaceuticals, e.g. cardiological drugs, about the occurrence of drug allergies and reminds to remove all metal elements of clothing or jewellery. Then the patient is secured and moves to the operating table. If the patient's health does not allow this -staff in accordance with intimacy and caution, moves the patient using special rollers. Then the patient is transported to the operating room and there is given anesthesia after previous monitoring. At a later stage, the surgical team together with the anesthesiological team securely places the patient on the operating table in a position adapted to the procedure.

\section{PATIENT SAFETY IN THE OPERATING THEATER}

The anesthesiological team deals with patient care and supervision before, during and after anesthesia. The tasks of anaesthesiological staff include patient monitoring (instrumental and non-instrumental), controlling bleeding intensity, recognition of respiratory and cardiovascular disorders, disturbances in the state of consciousness, thermoregulation, prevention of vomiting, coordination and monitoring of pain treatment, as well as recognition of transfusion complications. It is necessary to mention the need to inform and educate the patient (and his family or caregivers) about planned and performed medical activities. The patient staying in the operation theatre must be completely safe, therefore medical staff are required to be highly professional, self-disciplined, and above all, to cooperate and be kind to each other and patients. To ensure patient safety, it is also necessary to organize the right conditions in the operating theater and ward rooms. Current requirements for the equipment and operation of the operating theater are in the Regulation of the Minister of Health of November 10, 2006. A modern operating room must meet the requirements of efficient and clean air conditioning, adequate humidity (in Poland at 55-60\%), correct air movement (under pressure in the operating room). The temperature in the operating room still raises a lot of controversy because the operating team feels best when it is around $19^{\circ} \mathrm{C}$. For the patient, however, such a temperature is too low, it can cause body cooling and the consequences it brings. According to the regulations in Poland, the temperature in the operating room for 
adults should be $24-25^{\circ} \mathrm{C}$. The operating room should be equipped with non-heating shadowless lamps with double protection in the event of a power failure. In addition, the operating room should be of adequate size - not less than 35 $\mathrm{m}^{2}$, lined on the walls and floor with smooth, electrostatic material, easy to clean and disinfect, and (for psychological reasons) in a light color. The operating room should of course be equipped with the necessary, mobile, efficient and safe medical equipment.

\section{NURSING CARE IN THE PERIOPERATIVE PERIOD:}

Nursing care of a patient in the perioperative period is an important element in the treatment process. It is important that it is tailored to the individual needs of each patient and executed in a continuous, reliable and comprehensive manner. One of the main tasks in nursing care after surgery is to systematically minimize pain through the use of pharmacological agents to provide the patient with full comfort in the physical and mental sphere [27-30]. Reducing pain has a great impact on reducing the possibility of postoperative complications and facilitates the healing process, and thus shortens the hospitalization period [30]. Another essential activity in nursing care is providing the patient with the basic needs of everyday life. The nurse should assess the level of self-care deficits using selected scales, e.g. Barthel, and select the type of help based on the result. She should also assist and mobilize the patient to physical activity. As far as possible, early physical activation of the patient aims to restore fitness and accelerate the patient's independent functioning. Patient's education before and after surgery is very important [31]. This education should refer to the principles that should be followed to ensure the best treatment and improvement results [32]. The patient should receive recommendations on maintaining a healthy weight, proper lifestyle and safe ways of performing daily activities.

\section{PERIOPERATIVE STRESS}

Stress - an inseparable element of a patient's stay in hospital, occurs especially in the event of a threat to health or life, the appearance of a serious somatic disease or disability [33-37]. High levels of stress are usually associated with the extent of surgery $[38,36]$, the appearance of pain, complications or limitation of independence, and thus dependence on other people [36]. Its effects bring negative effects on treatment and significantly reduce the quality of life of patients, as well as their assessment of hospital stay $[35,36,39]$. Providing information support and ensuring a sense of security can reduce stress, but the most important is mental support, which combines with the ability to therapeutic communication, which makes the patient feel that he is understood by medical staff, and his fears have been heard and noticed [36, 40-42]. Better understanding of stress conditions experienced by patient can help eliminate some of the problems occurring in the pre- and postoperative period, as well as improve the quality of medical care $[36,43]$.

\section{DIFFERENCES AND CHARACTERISTICS OF NURSING CARE FOR PATIENTS WITH LARGE JOINT REPLACEMENTS}

Osteoarthritis of large joints affects a significant percentage of people over 65 (30\% of the population) [44, 45]. It results in pain, physical disability and a significant deterioration in the quality of life, which leads to loss of independence and dependence on the help of others [46-50]. In most cases, advanced degenerative disease requires surgery in the form of endoprosthesis. The most common challenges faced by nursing staff in patients with osteoarthritis in the perioperative period are: pain, significant reduction of the patient's fitness, and his fear as to the course of the procedure and the period immediately after it [51]. This is usually related to the extent of the planned surgery and the patient's personality, is the reason why emotional support is an important element of the quality of nursing care in the preparation the patient for the surgery $[38,52]$. The duty of the nurse is also to provide information to the patient $[51,53]$. The scope and type of support depends on the patient's current needs [38]. According to the literature, it is important to achieve a balance between the expected and obtained support $[38,54,55]$. Pain relief is another factor affecting patient satisfaction. It is an element of care which also aims to provide mental and physical comfort [56]. Published research results show that in assessing satisfaction with nursing care, an extremely important element is to preserve the patient's sense of dignity and intimacy during nursing activities [38]. In assessing overall patient satisfaction, timely assistance and response to patient requests are also important [53]. A very important aspect is also the time devoted to the patient and the completeness of the information provided to him [57]. Demographic variables such as gender, age, professional status and education have a significant impact on the level of patient satisfaction [58]. It is also worth noting that while in most of the analyzed works, the respondents did not have any reservations about the degree of attention devoted to them by nurses, they very often indicated the lack of sufficient attention and time devoted to the patient by doctors as a factor negatively affecting the assessment of the medical facility.

Numerous studies show that a high level of satisfaction with the received medical service is of strategic importance both in attracting new patients to the center and maintaining their loyalty [59]. In accordance with the philosophy of modern quality management in medical entities, patient satisfaction together with the knowledge and experience of staff as well as modern diagnostic methods is an important element of assessing the quality of healthcare. The modern view is dominated by the opinion that the patient is the most important subject of the medical activities, and satisfying his expectations - the main purpose of those activities [58]. In practical terms, the satisfaction level survey provides information on the needs and expectations of patients. It has also been proven that a high level of satisfaction has a positive effect on the results of treatment and a reduction in the number of its complications. Hence, deliberate attention to factors affecting its growth seems to 
be by all means important not only because of the potential economic benefits but also purely medical benefits.

\section{REFERENCES}

1. Stephens A, Rowberry T, Tyser AR, Kazmers NH. Evaluating opportunities for improved orthopedics outpatient satisfaction: an analysis of Press Ganey ${ }^{\circledR}$ Outpatient Medical Practice Survey responses. J Orthoped Surg Res. 2020;15:28.

2. Kowalska M. Po pierwsze relacje. 0SOZ 2011;4:14.

3. Małecka B, Marcinkowski JT. Satysfakcja pacjenta czynnikiem kształtującym współczesny rynek usług medycznych. Probl Hig Epidemiol. 2007;88(1):17-19.

4. Kapała W, Skrobisz J. Oczekiwania pacjentów hospitalizowanych w oddziale chirurgii trybem planowym względem zespołu lekarskiego, pielęgniarskiego i warunków lokalowych. Nowiny Lek. 2006;75:351-358.

5. Miśkiewicz M. Jakość, różne oczekiwania. Służba Zdr 1996;68/69(2568/2569).

6. Palmer R. Striving for quality in health care. Health Administation Press, Ann Harbor 1991.

7. Szzzerbińska K. Jakość opieki zdrowotnej. In: Czupryna A, PoździochS, Ryś A, Włodarczyk C (eds): Zdrowie publiczne. vol. 2. Vesalius, Kraków 2001, pp. 141-142, 177.

8. Czerw A. Satysfakcja i lojalność klienta na rynku farmaceutycznym. Cedewu Wydawnictwo Fachowe, Warszawa 2008.

9. Berkowska M. Satysfakcja pacjentów z usług medycznych odstawowej opieki zdrowotnej. In: *** Biuro Wielkopolskiej Unii OpiekiZdrowotnej: Wypracowane narzędzia do oceny jakości usług medycznych w podstawowej opiece zdrowotnej. BWUOZ, Poznań 1998, pp. 4-5:12-13.

10. Allen DR, Rao TR. Analysis of customer satisfaction data. ASQ Quality Press, 2000.

11. Kamińska-Rosner J, Zdun-Ryżewska A. Satysfakcja pacjentów z ambulatoryjnej opieki medycznej i jej uwarunkowania. Med Rodz 2013;3.

12. Hill N, Alexander J. Pomiar satysfakcji i lojalności klientów. Oficyna Ekonomiczna, Warszawa, 2003.

13. Woodruff RB, Gardial SF. Know your customer. New approaches to understanding customer value and satisfaction, Buckwell Publishers Inc., Cambridge, Mass 1996, p. 95.

14. Risser N. Development of an instrument to measure patient satisfaction with nurses and nursing care in primary care settings. Nurs Res. 1975;24:45-2.

15. Bank J. Zarządzanie przez jakość. Gebethner i S-ka, Warszawa 1997, p. 2.

16. Bukowska-Piestrzyńska A.: Marketing usługzdrowotnych od budowania wizerunku placówki do zadowolenia klientów. Wydawnictwo CeDeWu, Warszawa, 2010, pp. 17-18.

17. Waszkiewicz A, Białecka B. Kształtowanie usług medycznych na podstawie oceny i odczucia pacjenta. Zeszyty naukowe Politechniki Śląskiej. Seria: Organizacja i Zarządzanie 2012:63a:1891.

18. Kindalski E, Bagiński J. Podstawy zarządzania przez jakość. Wydawnictwo Profesjonalnej Szkoły Biznesu w Krakowie, Kraków, 1997.

19. Abramowitz S, Cote AA, Berry E. Analyzing patient satisfaction: a multianalytic approach. Q Rev Bulletin 1987;13:122-130.

20. Jacox AK, Bausell BR, Mahrenholz DM. Patient satisfaction with nursing care in hospitals. Outcom Manag Nurs Pract. 1997;1:20-28.

21. Chrzanowski R. Podnoszenie jakości usług medycznych w zakładach opieki zdrowotnej. Antidotum 1993;1:43-46.

22. Satel SL. When disability benefits make patients sicker. N Engl J Med. 1995;333:794-796.
23. Grabska K, Stefańska W. Sylwetka zawodowa pielęgniarki w opinii pacjentów, Problemy pielęgniarstwa 2009;17(1):8-12.

24. Gugała B, Iwanicka-Maciura A, Mryczko E. Oczekiwania rodzin pacjentów przewlekle chorych w zakresie opieki pielęgniarskiej. Med Ogól Nauki Zdr. 2012;18(3):225-228.

25. Anczewska M, Raduj J, Indulska A, Pałyska M, Prot K. Porównanie opinii pacjentów 0 jakości opieki na oddziałach psychiatrycznych i neurologicznych. Psych Pol. 2010;64:255-265.

26. Wyrzykowska M. Ocena opieki pielęgniarskiej w opinii pacjentów. Piel Chir Ang. 2007;1:3-10.

27. Kapała W. Pielęgniarstwo w chirurgii. Wybrane problemy z praktyki pielęgniarskiej oddziałów chirurgii ogólnej. Wyd. Czelej, Lublin 2006, pp. 193-196.

28. Kapała W, Skrobisz J. Oczekiwania pacjentów hospitalizowanych w oddziale chirurgii trybem planowym względem zespołu lekarskiego, pielęgniarskiego i warunków lokalowych. Nowiny Lek. 2006;75:351-358.

29. Lewandowski B, SierakowskiS, Kita K. Biodro - przyczyny najczęstszych dolegliwości. Nowa Med. 2002;2:31-35.

30. Skokowska B, BączykG,ZembrońE. Ocena jakości opieki pielęgniarskiej w zakresie bólu pooperacyjnego dokonywana przez chorych po zabiegach ortopedycznych. Pieleg Pol. 2016;3(61).

31. Kózka M. Wybrane standardy opieki pielęgniarskiej. UJ, Kraków, 1997.

32. Walewska E. Podstawy pielęgniarstwa chirurgicznego, PZWL, Warszawa, 2007.

33. Heszen-Klemens I. Psychologiczne problemy chorych somatycznie. In: Strelau J. (ed.). Psychologia, GPW, Gdańsk, 2000.

34. Heszen-Klemens I, Sęk H. Psychologia zdrowia. PWN, Warszawa, 1997.

35. Motyka M. Obawy pacjentów przygotowywanych do zabiegu operacyjnego. Sztuka Leczenia 2001;4:23-26.

36. MotykaM.,KamińskaM.,KochmanM.Stresprzedzabiegiemoperacyjnym, a przebieg okresu pooperacyjnego u pacjentów po wszczepieniu endoprotezy stawu biodrowego, Przegl Lek. 2016;73(1).

37. Sarafino E. Health Psychology. Biopsychosocial Interaction. Wiley \& Sons, New York, 2002.

38. Grochans E, Wieder-Huszla S, Jurczak A, Stanisławska M, Janic E, Szych Z.Wsparcie emocjonalne jako wyznacznik opieki pielęgniarskiej. Probl. Hig. Epidemiol. 2009;90:236-239.

39. Heszen-Klemens I. Psychologiczne problemy chorych somatycznie. In: Strelau J (ed.). Psychologia, GPW, Gdańsk, 2000.

40. KochańskaV. Rolaprzekazuinformacjipomiędzyzespołemterapeutycznym a pacjentem (na przykładzie Szpitala Zakonu Bonifratrów Św. Jana Grandego w Krakowie). Pieleg XXI W 2005;4:53-60.

41. Lesińska-Sawicka M, Grygorowicz E, Jałtuszewska S. Wybrane elementy jakości opieki medycznej w odniesieniu do stresu hospitalizowanych osób. Pieleg XXI W. 2007;3-4:51-56.

42. Motyka M, Bąk B. Psychologiczne przygotowanie do poważnych zabiegów ginekologicznych a przebieg okresu pooperacyjnego. Pieleg XXI W. 2008;2-3:23-24.

43. Gittel JH, Fairfield KM, Bierbaum B, et al. Impact of relational coordination on quality of care, postoperative pain and functioning, and length of stay: a nine hospital study of surgical patients. Med Care 2000;38:807-817.

44. Pop T, Hamerla K, Przysada G. Czynniki wpływające na redukcję bólu u chorych z chorobą zwyrodnieniową stawów kolanowych. Ortop Traumatol Rehabil. 2012;6(6);14:537-44.

45. Widuchowski J. Kolano - urazy i obrażenia sportowe. G-Kwadrat S.C. Katowice, 1997. 
46. Dega W. Ortopedia i rehabilitacja. vol II PZWL, Warszawa 1984, pp. 687-697.

47. Dega W. Ortopedia i traumatologia. Warszawa, 1996, PZWL.

48. Górecki A. Uszkodzenia stawu kolanowego. PZWL, Warszawa 2002.

49. Kiwerski J. Rehabilitacja medyczna. PZWL, Warszawa 2005, pp. 560-571, 576-579.

50. Milanowska K, Dega W. Rehabilitacja medyczna, PZWL, Warszawa 2001, 372-395.

51. Dyga-Konarska M. Informacyjne i emocjonalne wsparcie pacjenta przez personel medyczny. Stand Med. 2004;5:599-604.

52. Salmon P. Psychologia w medycynie. GWP, Gdańsk, 2002.

53. Grochans E, Seewald K, Szkup-Jabłońska M, et al. Satysfakcja z opieki pielęgniarskiej pacjentów pielęgnowanych tradycyjnie oraz w systemie Primary Nursing. Probl Piel. 2011;19:177-184.

54. Majasaari $\mathrm{H}$, et al. Patients' perceptions of emotional support and information provided to family members. AORN J 2005 [https://doi. org/10.1016/S0001-2092(06)60469-9].

55. Mijała J, KapałaW. Edukacja i wsparcie pacjentów hospitalizowanych ( $\mathrm{Na}$ przykładzie oddziałów chirurgicznych). Piel Pol 2002;2(14):262-269.

56. Idvall E, Berg K, Unosson M, et al. Differences between nurse and patient assessments on postoperative pain management in two hospitals. J Eval Clin Pract. 2005;11(5): 444-451.

57. Akhtari-Zavare M, Abdullah MY, Hassan STS, Said SB, Kamali M. Patient Satisfaction: Evaluating Nursing Care for Patients Hospitalized with Cancer in Teheran Teaching Hospitals, Iran. Global J. Of Health Science 2010;2:117-126.

58. Pawelczyk K, Maniecka-Bryła I, Targowski M, Samborska-Sablik A. Satysfakcja pacjentów jako jeden ze wskaźników jakości opieki medycznej na przykladzie poradni lekarza rodzinnego. Acta Clin Marpholog 2006;9(3):20-27.

59. Arab M, Ghazi Tabata Baei SM, Rashidian A, Rahimi Forushain A, Zarei E. The Effect of Service Quality on Patient loyalty: a Study of Private Hospitals in Teheran, Iran. Iranian J Publ Health 2012;41:71-77.

\section{ORCID and contributionship:}

Iwona Morawik 0000-0001-6998-3349 D,E

Monika Gospodarek 0000-0003-1827-1653 A,B,C,D

Karolina Turżańska 0000-0001-7359-9622 D,E,F

Aneta Zarebska 0000-0003-0208-7157 D

Anna Serefko 0000-0002-5732-8950 D

Mirosław Jabłoński 0000-0002-7490-4745 D,E,F

\section{Conflict of interest}

Authors declare no conflict of interest

\section{CORRESPONDING AUTHOR}

\section{Karolina Turżańska}

Chair and Department of Rehabilitation and Orthopaedics,

Medical University of Lublin, Lublin, Poland

Jaczewskiego str. 8, 20-954 Lublin, Poland

tel.: +48795833104

e-mail: karolina.turzanska@gmail.com

Received: 06.07 .2020

Accepted: 07.09.2020

A - Work concept and design, B - Data collection and analysis, C - Responsibility for statistical analysis,

D-Writing the article, $\mathbf{E}$-Critical review, $\mathbf{F}-$ Final approval of the article 